\title{
Effect of extracorporeal shock wave therapy on fracture healing in rat femural fractures with intact and excised periosteum
}

\author{
Ekstrakorporeal şok dalga tedavisinin periostu sağlam olan ve periostu eksize edilmiş \\ sıçan femurlarında kırık iyileşmesine etkisi
}

\author{
Birhan Oktaş, M.D., Zafer Orhan, M.D., ${ }^{2}$ Barış Erbil, M.D., ${ }^{2}$ Erdem Değirmenci, M.D., ${ }^{2}$ Nil Üstündağ, M.D. ${ }^{2}$ \\ 'Department of Orthopedics and Traumatology, Medical Faculty of Kırıkkale University, Kırıkkale, Turkey \\ ${ }^{2}$ Department of Orthopedics and Traumatology, Medical Faculty of Düzce University, Düzce, Turkey \\ ${ }^{3}$ Department of Pathology, Medical Faculty of İstanbul University, İstanbul, Turkey
}

Objectives: The aim of this study is to compare the effect of extracorporeal shock wave therapy (ESWT) on fractures with intact periosteum and excised periosteum.

Materials and methods: Thirty-seven Wistar albino rats were randomized into four groups. Osteotomy and intramedullary Kirschner wire fixation were performed on all right femurs under ketamin anesthesia. The first group $(n=10)$ was identified as control group. In the second group $(\mathrm{n}=10)$, periosteum located at the osteotomy site was excised circumferentially during surgery. In the third group $(n=9)$, periosteum was left intact and ESWT was applied. In the forth group $(n=8)$, periosteums of all rats were excised and ESWT was applied. All fracture lines were evaluated radiographically each two weeks and histologically at the sixth week. Results were evaluated statistically.

Results: In periosteum excised group which represents a model of open fractures with soft tissue defect, ESWT application had a significantly positive histologic effect on bone healing. However, radiological evaluation did not reveal any statistically significant difference between groups with intact and excised periosteums.

Conclusion: According to our findings, ESWT can be used to improve fracture healing and prevent pseudoarthrosis in the treatment of open fractures with accompanying soft tissue and periosteum damage. However, further clinical studies are required to include ESWT in routine practice.

Keywords: Extracorporeal shock wave treatment; fracture healing; lithotripsy; nonunion; open fracture; periosteum.

There are several factors identified as having negative or positive consequences on fracture healing. ${ }^{[1]}$ The configuration and status of the bone, periosteum and surrounding soft tissues also may have a role
Amaç: Bu çalışmada ekstrakorporeal şok dalga tedavisinin (ESWT) periostu sağlam olan ve periostu eksize edilmiş olan kırıklar üzerine etkisi karşıllaştırıldı.

Gereç ve yöntemler: Otuz yedi Wistar albino sıçan dört gruba randomize edildi. Ketamin anestezisi altında tüm sağ femurlara osteotomi ve intramedüller olarak Kirschnerteli tespiti uygulandı. İlk grup $(\mathrm{n}=10)$ kontrol grubu olarak tanımlandı. İkinci grupta $(\mathrm{n}=10)$, osteotomi hattındaki periost cerrahi sırasında çevresel olarak eksize edildi. Üçüncü grupta $(n=9)$, periost sağlam bırakılarak ESWT uygulandı. Dördüncü grupta $(\mathrm{n}=8)$, tüm sıçanların periostları eksize edildi ve ESWT uygulandı. Tüm kırık hatları iki haftada bir radyolojik olarak ve altıncı haftada histolojik olarak değerlendirildi. Sonuçlar istatistiksel olarak değerlendirildi.

Bulgular: Yumuşak doku defektli açık kırık modelini temsil eden, periostu eksize edilen grupta, ESWT uygulaması kırık iyileşmesi üzerinde anlamlı şekilde olumlu bir histolojik etkiye sahipti. Ancak radyolojik değerlendirme periostu sağlam olan ve eksize edilen gruplar arasında istatistiksel olarak anlamlı bir fark göstermedi.

Sonuç: Bulgularımıza göre, yumuşak doku ve periost hasarının eşlik ettiği açık kırık tedavisinde, kırık iyileşmesini hızlandırmak ve psödoartroz oluşumunu engellemek amacıyla ESWT kullanılabilir. Ancak ESWT'nin rutin uygulamaya dahil edilebilmesi için daha fazla klinik çalışma gereklidir.

Anahtar sözcükler: Ekstrakorporeal şok dalga tedavisi; kırık iyileşmesi; litotripsi; kaynamama; açık kırık; periost.

in fracture healing. Open fractures are under risk of infection and delayed healing due to loss of periosteum and soft tissue coverage. In recent years, extracorporeal shock wave therapy (ESWT) is being

- Received: October 08, 2013 Accepted: April 30, 2014

- Correspondence: Birhan Oktaş, M.D. Kırıkkale Üniversitesi Tıp Fakültesi Ortopedi ve Travmatoloji Anabilim Dalı, 71450 Yahşihan, Kırıkkale, Turkey. Tel: +90 505 - 2401491 Fax: +90 318-2252819 e-mail: birhanoktas@yahoo.com.tr 
used in the treatment of nonunions and delayed unions as well as humeral epicondylitis, plantar fasciitis and calcifying tendinitis. ${ }^{[2]}$ The effect of ESWT in non- and delayed union of fractures is reported in many studies. ${ }^{[3-5]}$ None of these studies evaluates the primary fracture with regard to fracture hematoma and periosteum loss. In this study, we aimed to compare the effect of ESWT on fractures with intact periosteum and excised periosteum.

\section{MATERIALS AND METHODS}

This study was performed with the approval of Animal Care Committee of our institution. Thirty-seven Wistar albino rats of the same generation were randomized into four groups. In all groups, transverse osteotomy was performed on diaphysis of femurs under general anesthesia using $50 \mathrm{mg} / \mathrm{kg}$ Ketamin $\mathrm{HCl}$ (Ketalar ${ }^{\circledR}$ ) to simulate a fracture. All fractures were stabilized with a retrograde intramedullary $0.6 \mathrm{~mm}$ Kirschner wire (Figure 1). In the control group (group 1) $(n=10)$, the periosteum was incised meticulously and conserved during osteotomy. No additional treatment was applied. In group $2(\mathrm{n}=10)$, the periosteum was excised circumferentially at the osteotomy site and no additional treatment was applied. In group $3(n=9)$, the periosteum was left intact and ESWT was applied after the fracture fixation. In group $4(n=8)$, ESWT was applied after circumferential excision of the periosteum and fracture formation and stabilization.
Extracorporeal shock wave therapy was applied after the closure of incision with Stonelith $\mathrm{PCK}^{\circledR}$ lithotripter (Turkey, Ankara) under general anesthesia (Figure 2). During ESWT, 500 impulses of shock wave at $15 \mathrm{kV}$ were applied in group 3 and $4 .^{[6]}$ The fractures were evaluated blindly by a radiologist on anteroposterior and lateral radiographs of femora at $0,2,4$ and $6^{\text {th }}$ weeks postoperatively and graded according to scale of Lane and Sandh ${ }^{[7]}$ Bone formation, union and remodeling were scored on this scale.

At postoperative sixth week, all rats were sacrificed and the fracture sites were evaluated blindly by a pathologist according to the scale of Allen et al. ${ }^{[8]}$ In this scale, the union site is graded according to fibrous, cartilaginous or bony union.

Data from the radiographic evaluation were divided into two major groups. First group included rats having 0-3 points, and second group included rats having 4-12 points. These major groups were compared according to ESWT application and periosteum existence. $\mathrm{P}$ values lower than 0.05 were considered significant.

Data from histological evaluation were also divided into two major groups according to occlusion of the fracture line. First group included rats having less than 2 points, and second group included rats having more than 2 points. These major groups were also compared according to ESWT application
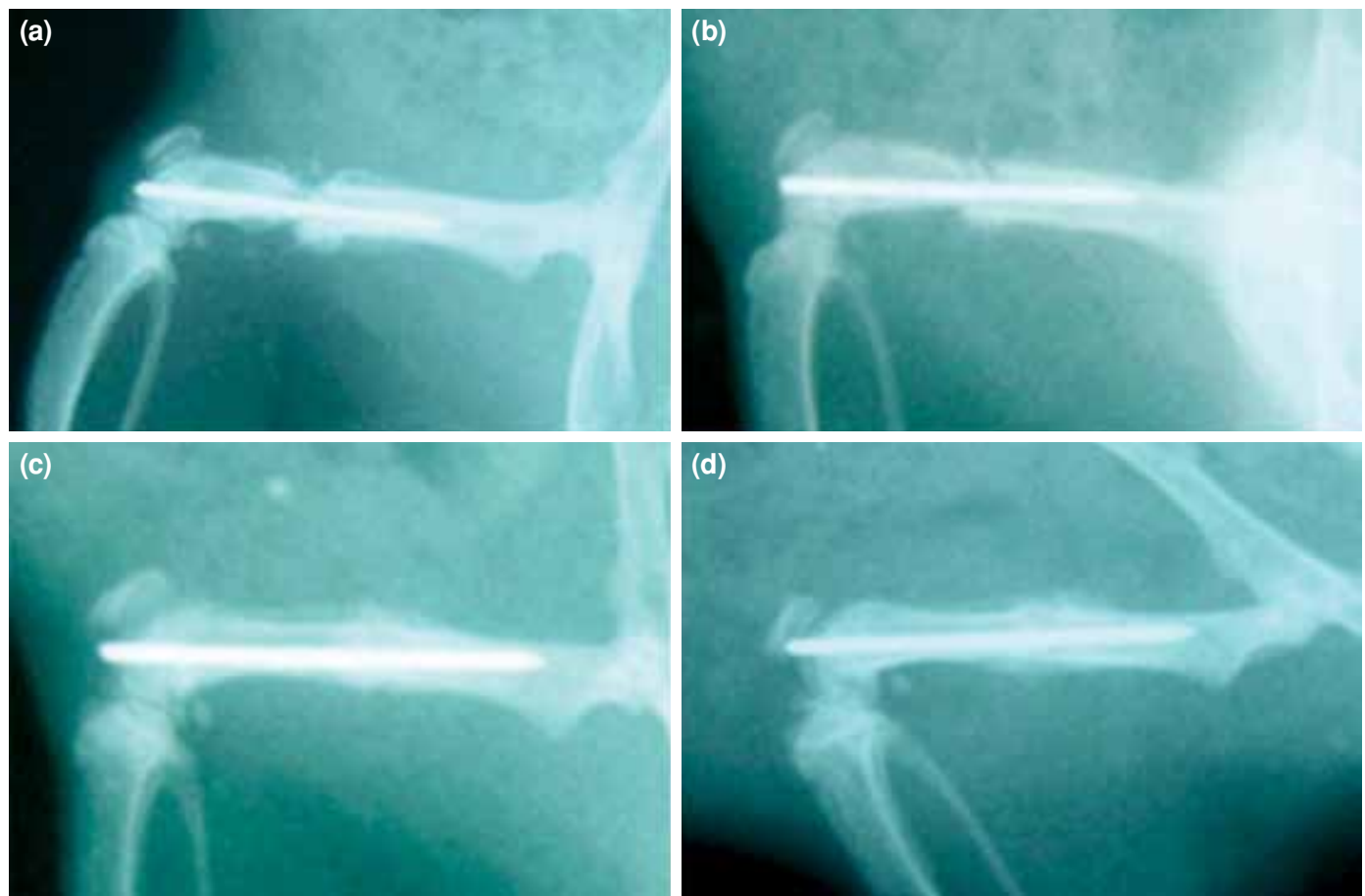

Figure 1. Direct radiography of rat femurs at the end of therapy. (a) Group 1 (P+, E-); (b) group 2 (P-, E-); (c) group $3\left(P_{+}, E_{+}\right)$; (d) group $4\left(P_{-}, E_{+}\right)$. 


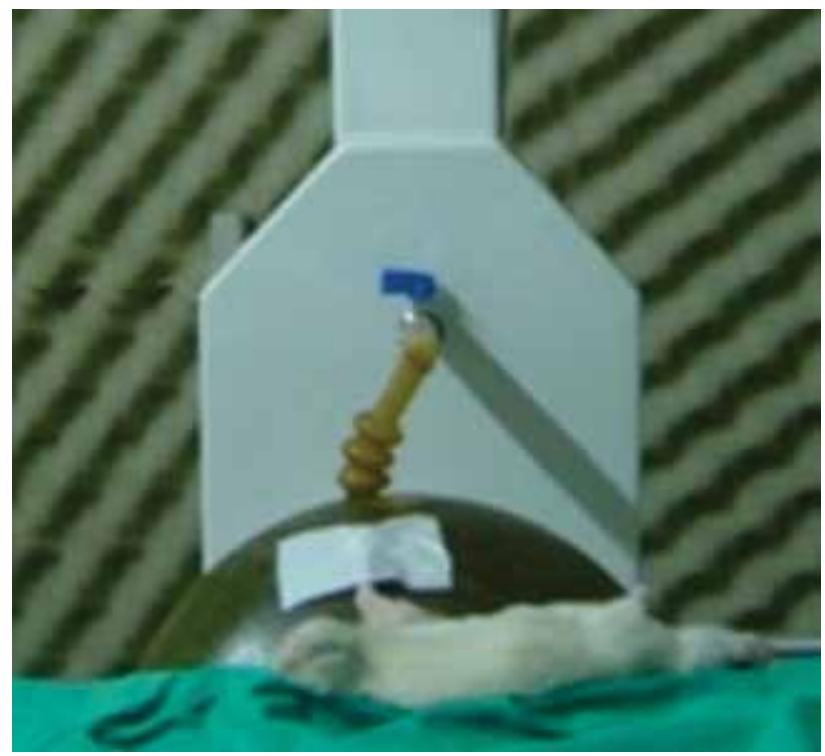

Figure 2. Stonelith $\mathrm{PCK}^{\circledR}$ lithotripter.

and periosteum existence. We used Fisher's exact importance test. $\mathrm{P}$ values lower than 0.05 were accepted as statistically significant.

\section{RESULTS}

Mean histological and radiological scores for each group were calculated and total scores were obtained (Table I).

Radiological scores in group 1 and 2 were statistically lower than group 3 and $4 \quad(\mathrm{p}<0.05)$. There was no statistically significant difference in radiological scores between groups 3 and 4 . Histological score in group 2 was statistically lower than the other groups $(p<0.05)$. There was no statistically significant difference between other groups.

\section{DISCUSSION}

In recent years, many biochemical factors like misoprostol, ${ }^{[9]}$ melatonin, ${ }^{[10]}$ strontium ranelate, ${ }^{[11]}$ leptin $^{[12]}$ and mesenchymal stem cells ${ }^{[13]}$ are shown to improve fracture healing. Low-intensity pulsed ultrasound, ${ }^{[14]}$ electromagnetic and electric fields ${ }^{[15]}$ have been also shown to accelerate fracture healing as mechanical factors. According to the literature, ESWT is also used in musculoskeletal system for fracture healing and nonunion treatment, as well as calcific tendinitis and pseudoarthrosis. ${ }^{[2-6]}$

In our study, we aimed to show the effect of ESWT on fracture healing in periosteum deficient open fractures. Fractures with deficient periosteum and surrounding soft tissues are under risk of nonunion or delayed union. Highest scores in our study were obtained in ESWT applied fractures with intact periosteum. In the literature, positive effects of ESWT have been shown in many clinical studies. ${ }^{[16,17]}$ However, its mechanism is still controversial. Wang et al. ${ }^{[18]}$ searched bone healing effect of ESWT on rabbit femur fracture model. The shockwave group showed significantly higher numbers of neovessels and immunopositive cells including vessel endothelial growth factor, endothelial nitric oxide synthase, proliferating cell nuclear antigen, and bone morphological protein-2 than the control. ${ }^{[18]}$ In recent studies, differentiation of mesenchymal stem cells and promotion of angiogenesis via increased expression of several growth factors have been suggested also as bone forming effects of shockwaves. ${ }^{[19-21]}$

Statistically significant difference was detected between group 2 and 4. Our radiological and histological comparisons of the effect of ESWT application on periosteum deficient fractures revealed that periosteum is significant in callus formation and bone healing $(\mathrm{p}<0.05)$. Many studies related to the periosteum showed that periosteum serves as a niche for progenitor cells and supplies a rich vascularization to the bone which it envelops. ${ }^{[22]}$ In our study, ESWT applied groups (group 3 and 4) had statistically similar results. Instead of periosteum, ESWT may play a role for releasing local growth factors and the recruitment of appropriate stem cells leading to improved tissue healing. ${ }^{[23]}$ Another theory

\section{TABLE I}

Histological and radiological scores in all rat groups

\begin{tabular}{|c|c|c|c|c|c|c|}
\hline Groups & Periosteum & ESWT & Number of rats & Histological mean score & Radiological mean score & Total scores \\
\hline 1 & $(+)$ & - & 10 & 2.3 & 3.9 & 6.2 \\
\hline 2 & - & - & 10 & 1.5 & 2.3 & 3.8 \\
\hline 3 & $(+)$ & $(+)$ & 9 & 3.4 & 6.8 & 10.2 \\
\hline 4 & - & $(+)$ & 8 & 3.4 & 6.4 & 9.8 \\
\hline Total & & & 37 & & & \\
\hline
\end{tabular}


for its mechanism is that it causes micro fractures in the cortex by stimulating the interaction of gas bubbles, which is also called cavitation effect. ${ }^{[2]}$

Shock waves are also used in the treatment of pseudoarthrosis and delayed union. ${ }^{[19,21]}$ Union is achieved in most cases with a single ESWT session coupled with standard fracture immobilization techniques in nonunions. Bulut et al. ${ }^{[21]}$ showed an accelerated bone union in a defective nonunion model in rabbits. Atrophic nonunions seem to have a poorer outcome in comparison with the hypertrophic nonunions in shock wave therapy. ${ }^{[4]}$ Notarnicola et al. ${ }^{[5]}$ compared ESWT and standard surgery in scaphoid nonunion at 350 patients. They showed no significant difference between two groups at the $2^{\text {nd }}, 6^{\text {th }}$ and $12^{\text {th }}$ months follow-up according to radiographic consolidation or the Mayo Wrist Score. They suggest that shock wave therapy should be considered as the second choice of treatment in the cases which show clinical and radiographic healing delay after surgical stabilization. ${ }^{[5]}$

In conclusion, ESWT has been studied as a nonsurgical way to achieve fracture healing. Thanks to its advantages such as noninvasiveness, ease to apply and low complication rate, ESWT has been widely used in the treatment of nonunions in various experimental and clinical studies. In our study, ESWT application accelerated fracture healing in the periosteum excised fractures similar to fractures with intact periosteum. In the future, ESWT may be applied as an adjuvant treatment for open long bone fractures which are under the risk of nonunion. On the other hand, rat studies do not show the same correlation with human applications. Therefore, further clinical studies are required to confirm our results.

\section{Declaration of conflicting interests}

The authors declared no conflicts of interest with respect to the authorship and/or publication of this article.

\section{Funding}

The authors received no financial support for the research and/or authorship of this article.

\section{REFERENCES}

1. Akkaya S, Nazalı M, Kılıç A, Bir F. Cefazolin-sodium has no adverse effect on fracture healing in an experimental rabbit model. Eklem Hastalik Cerrahisi 2012;23:44-8.

2. Wang CJ. An overview of shock wave therapy in musculoskeletal disorders. Chang Gung Med J 2003;26:220-32.

3. Elster EA, Stojadinovic A, Forsberg J, Shawen S, Andersen RC, Schaden W. Extracorporeal shock wave therapy for nonunion of the tibia. J Orthop Trauma 2010;24:133-41..

4. Birnbaum K, Wirtz DC, Siebert CH, Heller KD. Use of extracorporeal shock-wave therapy (ESWT) in the treatment of non-unions. A review of the literature. Arch Orthop Trauma Surg 2002;122:324-30.

5. Notarnicola A, Moretti L, Tafuri S, Gigliotti S, Russo S, Musci L, Moretti B. Extracorporeal shockwaves versus surgery in the treatment of pseudoarthrosis of the carpal scaphoid. Ultrasound Med Biol 2010;36:1306-13.

6. Lai JP, Wang FS, Hung CM, Wang CJ, Huang CJ, Kuo YR. Extracorporeal shock wave accelerates consolidation in distraction osteogenesis of the rat mandible. J Trauma 2010;69:1252-8. doi: 10.1097/TA.0b013e3181cbc7ac.

7. Lane JM, Sandhu HS. Current approaches to experimental bone grafting. Orthop Clin North Am 1987;18:213-25.

8. Allen HL, Wase A, Bear WT. Indomethacin and aspirin: effect of nonsteroidal anti-inflammatory agents on the rate of fracture repair in the rat. Acta Orthop Scand 1980;51:595-600.

9. Milcan A, Colak M, Eskandari G. Misoprostol enhances early fracture healing: a preliminary biochemical study on rats. Bone 2007;41:611-3.

10. Halıcı M, Öner M, Güney A, Canöz Ö, Narin F, Halıcı C. Melatonin promotes fracture healing in the rat model. Eklem Hastalik Cerrahisi 2010;21:172-7.

11. Cebesoy O, Tutar E, Kose KC, Baltaci Y, Bagci C. Effect of strontium ranelate on fracture healing in rat tibia. Joint Bone Spine 2007;74:590-3.

12. Kerimoğlu G, Yuluğ E, Kerimoğlu S, Çıtlak A. Effects of leptin on fracture healing in rat tibia. Eklem Hastalik Cerrahisi 2013;24:102-7.

13. Fayaz HC, Giannoudis PV, Vrahas MS, Smith RM, Moran C, Pape $\mathrm{HC}$, et al. The role of stem cells in fracture healing and nonunion. Int Orthop 2011;35:1587-97.

14. Oliveira P, Sperandio E, Fernandes KR, Pastor FA, Nonaka $\mathrm{KO}$, Renno AC. Comparison of the effects of low-level laser therapy and low-intensity pulsed ultrasound on the process of bone repair in the rat tibia. Rev Bras Fisioter 2011;15:200-5.

15. Ryaby JT. Clinical effects of electromagnetic and electric fields on fracture healing. Clin Orthop Relat Res 1998; (355 Suppl):S205-15.

16. Wang CJ, Liu HC, Fu TH. The effects of extracorporeal shockwave on acute high-energy long bone fractures of the lower extremity. Arch Orthop Trauma Surg 2007;127:137-42.

17. van der Jagt OP, Piscaer TM, Schaden W, Li J, Kops N, Jahr H, et al. Unfocused extracorporeal shock waves induce anabolic effects in rat bone. J Bone Joint Surg [Am] 2011;93:38-48.

18. Wang CJ, Wang FS, Yang KD. Biological effects of extracorporeal shockwave in bone healing: a study in rabbits. Arch Orthop Trauma Surg 2008;128:879-84.

19. Wang CJ, Yang KD, Ko JY, Huang CC, Huang HY, Wang FS. The effects of shockwave on bone healing and systemic concentrations of nitric oxide (NO), TGF-beta1, VEGF and BMP-2 in long bone non-unions. Nitric Oxide 2009;20:298-303.

20. Hausdorf J, Sievers B, Schmitt-Sody M, Jansson V, Maier M, Mayer-Wagner S. Stimulation of bone growth factor synthesis in human osteoblasts and fibroblasts after extracorporeal shock wave application. Arch Orthop Trauma Surg $2011 ; 131: 303-9$.

21. Bulut O, Eroglu M, Ozturk H, Tezeren G, Bulut S, Koptagel E. Extracorporeal shock wave treatment for defective nonunion of the radius: a rabbit model. J Orthop Surg 
(Hong Kong) 2006;14:133-7.

22. Knothe UR, Dolejs S, Matthew Miller R, Knothe Tate ML. Effects of mechanical loading patterns, bone graft, and proximity to periosteum on bone defect healing. J Biomech 2010;43:2728-37.
23. Martini L, Giavaresi G, Fini M, Borsari V, Torricelli P, Giardino R. Early effects of extracorporeal shock wave treatment on osteoblast-like cells: a comparative study between electromagnetic and electrohydraulic devices. J Trauma 2006;61:1198-206. 